\title{
TARAF SINKRONISASI HORIZONTAL PENGATURAN IZIN USAHA PERTAMBANGAN BERDASARKAN UNDANG-UNDANG NOMOR 4 TAHUN 2009 TENTANG PERTAMBANGAN MINERAL DAN BATUBARA DAN UNDANG-UNDANG NOMOR 9 TAHUN 2015 TENTANG PERUBAHAN KEDUA UNDANG-UNDANG NOMOR 23 TAHUN 2014 TENTANG PEMERINTAHAN DAERAH
}

\author{
Putri Noor Ilmi \\ Email: putrinoorilmi@gmail.com \\ Mahasiswa Fakultas Hukum Universitas Sebelas Maret Surakarta \\ Moch. Najib Imanullah \\ Email: najibimanullah@staff.uns.ac.id \\ Dosen Fakultas Hukum Universitas Sebelas Maret Surakarta \\ Scopus ID: 57201684060
}

\begin{abstract}
The authority to issue Mining Business Licenses based on Law Number 4 of 2009 concerning Mineral and Coal Mining is owned by the Central Government, Provincial Government and Regency/City Government. Meanwhile, based on Law Number 9 of 2015 concerning the Second Amendment to Law Number 23 of 2014 concerning Regional Government the authority to issue Mining Business Permits is owned by the Central Government and the Provincial Government. This article objective to discuss the implications of the regulation of mining business licenses that are not synchronized and efforts to synchronize the regulation of Mining Business Permits. This article is a descriptive analytical legal research. This research was carried out by the law approach. The data used are secondary data, namely the statutory provisions, the Regulation of the Minister of Energy and Mineral Resources, and the mining law literature with the technique of collecting study documents or library materials. So that the implications of these asynchronous arrangements can be resolved and the creation of an ideal Mining Business Permit arrangement.
\end{abstract}

Keywords: Synchronization; Implications; Mining Business Licenses; Investment.

\begin{abstract}
Abstrak
Kewenangan penerbitan Izin Usaha Pertambangan berdasarkan Undang-Undang Nomor 4 Tahun 2009 tentang Pertambangan Mineral dan Batubara dimiliki oleh Pemerintah Pusat, Pemerintah Provinsi, dan Pemerintah Kabupaten/Kota. Sedangkan berdasarkan Undang-Undang Nomor 9 Tahun 2015 tentang Perubahan Kedua Undang-Undang Nomor 23 Tahun 2014 tentang Pemerintahan Daerah kewenangan penerbitan Izin Usaha Pertambangan dimiliki oleh Pemerintah Pusat dan Pemerintah Provinsi. Artikel ini bertujuan untuk membahas mengenai implikasi pengaturan Izin Usaha Pertambangan yang tidak sinkron dan upaya sinkronisasi pengaturan Izin Usaha Pertambangan. Artikel ini merupakan penelitian hukum doktrinal yang bersifat deskriptif analitis. Penelitian ini dilakukan dengan pendekatan undang-undang. Data yang digunakan merupakan data sekunder yaitu ketentuan perundang-undangan, Peraturan Menteri Energi dan Sumber Daya Mineral, dan literatur hukum pertambangan dengan teknik pengumpulan data studi dokumen atau bahan pustaka. Sehingga implikasi dari pengaturan yang tidak sinkron tersebut dapat diselesaikan dan terciptanya pengaturan Izin Usaha Pertambangan yang ideal.
\end{abstract}

Kata Kunci: Sinkronisasi; Implikasi; Izin Usaha Pertambangan; Investasi. 
Putri Noor Ilmi, Moch.Najib Imanullah. Taraf sinkronisasi horizontal pengaturan izin usaha ....

\section{A. Pendahuluan}

Pasal 33 ayat (3) Undang-Undang Dasar Negara Republik Indonesia Tahun 1945 amandemen keempat mengatur bahwa "Bumi, air dan kekayaan alam yang terkandung di dalamnya dikuasai oleh Negara dan dipergunakan untuk sebesar-besarnya kemakmuran rakyat." Dalam penjelasan pasal tersebut peran dari Negara dalam pengelolaan sumber daya alam dalam hal ini mineral dan batubara sangat besar, dan melarang adanya penguasaan sumber daya alam di tangan orang-seorang.

Berdasarkan peraturan Mahkamah Konstitusi, sumber daya alam di Indonesia harus dikuasai oleh Negara agar tercipta kesejahteraan Negara (welfare state) (Jamiz Hamidi, 2015: 83). Sumber daya alam yang berkaitan dengan kemaslahatan umum (public utilities) dan pelayanan umum (public services), harus dikuasai Negara dan dijalankan oleh Pemerintah. Sebab sumber daya alam tersebut harus dapat dinikmati oleh rakyat secara berkeadilan, keterjangkauan, dalam suasana kemakmuran dan kesejahteraan umum yang adil dan merata (J. Ronald Mawuntu, 2012: 8).

Pemerintah menerbitkan Undang-Undang Nomor 11 Tahun 1967 tentang KetentuanKetentuan Pokok Pertambangan. Akan tetapi, undang-undang ini dianggap tidak sesuai dengan situasi saat ini dan di masa depan. Sehingga lahirlah Undang-Undang Nomor 4 Tahun 2009 tentang Pertambangan Mineral dan Batubara (selanjutnya disebut UU Minerba). UU Minerba bertujuan untuk memberikan tingkat yang lebih tinggi terkait perlindungan lingkungan dan hak masyarakat lokal. Kedutaan Besar AS di Jakarta menguraikan unsurunsur perubahan undang-undang penambangan yang baru yaitu reklasifikasi sumber daya alam; reklasifikasi para pihak; penanaman modal asing; lisensi/izin penambangan; operasi penambangan; pajak dan retribusi; pemurnian dan pengelolaan; desentralisasi; kewajiban pemberdayaan masyarakat; dan aturan tambahan (Bhasin \& Venkataramany, 2007: 6- 8).

Di Konawe Selatan, Provinsi Sulawesi Tenggara merupakan salah satu daerah yang mendapat manfaat dari UU Minerba yang baru. Di wilayah Torobulu, Konawe Selatan konsensi lahan PT Inco seluas 2.500 hektar menjadi tempat tinggal. Pada tahun 2010 PT Inco Tbk tidak melakukan eksplorasi/eksploitasi di Konawe Selatan dan tidak membayar sewa tanah kepada pemerintah setempat sesuai kesepakatan (Laporan Penelitian, UHO, 2015). Pada tahun 2010, sejalan dengan kebijakan penambangan mineral baru, seluruh area konsesi PT Inco Tbk diserahkan kepada Pemerintah Konawe Selatan. Selanjutnya, Pemerintah daerah menyediakan Izin Usaha Penambangan kepada investor baru, yaitu PT Billy Indonesia (La Ode, Syam Alam, \& Jamal Bake, 2016: 68).

Pelaksanaan hukum pertambangan yang baru ini berdampak terhadap iklim investasi yang lebih buruk di sektor pertambangan karena birokrasi fragmentasi, kapasitas institusional lokal dan regional yang tidak memadai, korupsi Pemerintah daerah dan penangkapan, menjamurnya tugas dan retribusi lokal, legislasi lokal yang lemah dan pelaksanaan hukum yang tidak efektif (Ana Duek \& Ridwan Rusli, 2010: 12-13). Izin yang diberikan kepala daerah kepada pelaku usaha diduga banyak disertai dengan imbal jasa (kickback) dalam bentuk suap atau gratifikasi. Kondisi tersebut diperparah dari rantai pengawasan yang tidak ketat oleh penyelenggara Negara (Komisi Pemberantas Korupsi, 2017: 1).

Pada tanggal 2 Oktober 2014 disahkannya Undang-Undang Nomor 23 Tahun 2014 tentang Pemerintahan Daerah yang telah diubah menjadi Undang-Undang Nomor 9 Tahun 
2015 tentang Perubahan Kedua Undang-Undang Nomor 23 Tahun 2014 tentang Pemerintahan Daerah (selanjutnya disebut UU Pemda) menjadikan daerah memiliki otonomi luas, nyata dan bertanggung jawab. Melalui UU Pemda, kewenangan pengelolaan SDA di kabupaten/ kota di beberapa sektor, diantaranya merupakan bidang kelautan dan perikanan, kehutanan serta energi dan sumber daya mineral dihapus.

Banyak terjadi permasalahan di lapangan sehubungan dengan pelaksanaan pengusahaan di bidang pertambangan, karena terjadi ketidakpastian hukum dalam penerapan berbagai peraturan perundang-undangan dan persepsi yang berbeda dengan kewenangan pemberian izin, serta terjadi ketidakharmonisan antar berbagai sektor terkait (Dwi Aryani W, 2016: 7). Sehingga perlu dikaji implikasi dari pengaturan Izin Usaha Pertambangan (IUP) yang tidak sinkron yang berdampak terhadap kegiatan investasi di sektor pertambangan mineral dan batubara serta upaya sinkronisasi dan alternatif solusi permasalahan tersebut.

\section{B. Metode Penelitian}

Jenis penelitian yang digunakan dalam penulisan hukum ini merupakan penelitian hukum doktrinal dengan sifat deskriptif analitis. Penelitian ini menggunakan pendekatan undangundang. Data yang digunakan merupakan bahan-bahan sekunder. Data sekunder mencakup bahan hukum primer berupa peraturan perundang-undangan dan bahan hukum sekunder berupa buku-buku teks, jurnal, artikel, dan bahan dari media internet (Soerjono Soekanto dan Sri Mamudji, 2007: 12-28). Teknik pengumpulan data yang digunakan penulis merupakan studi dokumen atau bahan pustaka.

\section{Hasil Penelitian dan Pembahasan}

1. Taraf Sinkronisasi Hukum

Sinkronisasi Menurut Kamus Besar Bahasa Indonesia (Departemen Pendidikan Nasional 2012, 1314), kata sinkron berarti terjadi atau berlaku pada waktu yang sama, serentak, sejajar, sesuai, selaras. Sinkronisasi yaitu perihal menyinkronkan, penyerentakan. Maksud dari kegiatan sinkronisasi merupakan agar substansi yang diatur dalam produk perundang-undangan tidak tumpang tindih, saling melengkapi (suplementer), saling terkait, dan semakin rendah jenis pengaturannya maka semakin detail dan operasional materi muatannya. Tujuan dari kegiatan sinkronisasi merupakan untuk mewujudkan landasan pengaturan suatu bidang tertentu yang dapat memberikan kepastian hukum yang memadai bagi penyelenggaraan bidang tersebut secara efisien dan efektif (Widhya Mahendra Putra, 2010: 30).

Sinkronisasi peraturan perundang-undangan dapat dilakukan dengan dua cara, yaitu :

a. Sinkronisasi Vertikal

Menurut Endang Sumiarni (2013: 5), sinkronisasi yang dimaksud merupakan dengan melihat kesesuaian atau keselarasan peraturan perundang-undangan secara vertikal berdasarkan sistematisasi hukum positif yaitu antara peraturan perundangundangan yang lebih rendah.

b. Sinkronisasi Horizontal

Dilakukan dengan melihat pada berbagai peraturan perundang-undangan yang sederajat dan mengatur bidang yang sama atau terkait. Sinkronisasi horizontal juga 
harus dilakukan secara kronologis, yaitu sesuai dengan urutan waktu ditetapkannya peraturan perundang-undangan yang bersangkutan. Sinkronisasi horizontal dapat diselesaikan/dibantu dengan menggunakan dua asas hukum yaitu lex posteriori derogate lex periori (Peraturan Perundang-undangan yang baru mengesampingkan peraturan/undang-undang yang lama) dan lex specialis derogate lex generalis (Peraturan Perundang-undangan yang bersifat khusus mengesampingkan peraturan/ undang-undang yang bersifat umum) (Zainudin Ali, 2009: 28).

2. Ketidaksinkronan Pengaturan Izin Usaha Pertambangan

Berdasarkan Pasal 8 ayat (1) Undang-Undang Minerba Pemerintah Kabupaten/ Kota dalam pengelolaan pertambangan mineral dan batubara diberikan kewenangan pemberian IUP dan IPR, pembinaan, penyelesaian konflik masyarakat, dan pengawasan usaha pertambangan di wilayah kabupaten/ kota dan/ atau wilayah laut sampai dengan 4 (empat) mil; pemberian IUP dan IPR, pembinaan, penyelesaian konflik masyarakat dan pengawasan usaha pertambangan operasi produksi yang kegiatannya berada di wilayah kabupaten/kota dan/atau wilayah laut sampai dengan 4 (empat) mil.

Sedangkan berdasarkan Pasal 14 ayat (1) Undang-Undang Pemda mengatur bahwa urusan Pemerintahan bidang kehutanan, kelautan, serta energi dan sumber daya mineral dibagi antara Pemerintah Pusat dan Pemerintah Provinsi. Pengaturan tersebut diatur secara rinci dalam lampiran Undang-Undang Pemda bagian CC sub urusan mineral dan batubara, pemerintah daerah provinsi diberi kewenangan penetapan wilayah IUP mineral bukan logam dan batuan dalam 1 (satu) Daerah provinsi dan wilayah laut sampai dengan 12 mil; penerbitan IUP dalam rangka penanaman modal dalam negeri pada wilayah IUP Daerah yang berada dalam 1 (satu) Daerah provinsi termasuk wilayah laut sampai dengan 12 mil laut; IUP Operasi Produksi Khusus untuk pengolahan dan pemurnian dalam rangka penanaman modal dalam negeri yang komoditas tambangnya berasal dari 1 (satu) Daerah provinsi yang sama; penerbitan izin usaha jasa pertambangan dan surat keterangan terdaftar dalam rangka penanaman modal dalam negeri yang kegiatan usahanya dalam 1 (satu) Daerah provinsi. Kewenangan penerbitan IUP di wilayah yang berada lintas provinsi menjadi kewenangan pemerintah pusat.

3. Implikasi dari Ketidaksinkronan Pengaturan Izin Usaha Pertambangan

Penerbitan IUP banyak yang tumpang tindih. Sebagai contoh yang terjadi di Konawe Utara, dimana PT Bososi dan PT Paramita melakukan kegiatan di kawasan hutan lindung padahal belum mendapatkan izin pinjam pakai kawasan hutan. Ada kemungkinan perbuatan nekat tersebut dilakukan karena penambang telah mendapat IUP dari Bupati Konawe Utara sehingga merasa telah diizinkan untuk menambang di wilayah kabupaten Konawe Utara (Dian Cahyaningrum, 2014: 100).

Kondisi pembagian wilayah pertambangan yang tumpang tindih menjadi dasar perlu dilakukannya penataan yang ditegaskan dalam Peraturan Menteri Energi Sumber Daya Mineral Nomor 43 Tahun 2015 tentang Tata Cara Evaluasi Penerbitan Izin Usaha Pertambangan Mineral dan Batubara. Evaluasi dokumen perizinan dilakukan terhadap IUP penyesuaian dari KP dan/atau KP yang belum berakhir jangka waktunya tetapi belum disesuaikan menjadi IUP. Evaluasi berdasarkan kriteria administratif, kewilayahan, teknis, dan finansial. Hasil dari evaluasi menghasilkan IUP dengan status IUP Clear 
and Clean $(\mathrm{CnC})$ dan IUP Non Clear and Clean (Non CnC). IUP CnC merupakan IUP yang wilayahnya tidak tumpang tindih dan/atau perizinannya tidak bermasalah sehingga dapat masuk dalam Wilayah Usaha Pertambangan. Sedangkan IUP Non $\mathrm{CnC}$ merupakan IUP yang perizinannya bermasalah dan /atau wilayahnya tumpang tindih. Perusahaan yang IUP berstatus Non $\mathrm{CnC}$ akan menghadapi beberapa permasalahan. Dalam aspek bisnis, ketika perusahaan ingin menjual atau bekerjasama dengan pihak lain tentunya akan dilihat potensi bisnis kedepan terkait legalitas IUP tersebut. Perusahaan yang IUP berstatus Non $\mathrm{CnC}$ akan mengurangi minat penjual atau investor untuk menerima tawaran bisnis tersebut (Nazaruddin Lathif, 2017: 161).

Sebagai contoh pada kasus PT IMFA. Permasalahan IMFA bermula dari tindakan IMFA pada tahun 2010 yang membeli PT Sri Sumber Rahayu Indah, pemilik IUP batubara di Barito Timur. Namun, PT IMFA merasa rugi karena telah mengeluarkan uang sebesar USD8,7 juta untuk membeli PT Sri Sumber Rahayu Indah, tetapi tidak dapat menambang karena IUP milik PT Sri Sumber Rahayu Indah bertumpuk-tumpuk dengan IUP 7 (tujuh) perusahaan lain. Izin yang tidak clear and clean $(\mathrm{CnC})$ itu membuat INFA tidak dapat berproduksi (Ahmad Redi, 2017: 108).

Istilah investasi atau penanaman modal banyak digunakan dalam kegiatan bisnis sehari-hari maupun dalam bahasa perundang-undangan. Istilah investasi banyak digunakan dalam dunia usaha, maka istilah penanaman modal banyak digunakan dalam perundang-undangan (Hartana, 2017: 58).

Sebelum calon investor menanamkan modalnya di suatu negara, ada beberapa hal yang yang menjadi perhatian negara calon investor. Hal yang menjadi perhatian bagi investor yaitu keamanan investasi yang sering berkaitan dengan stabilitas politik di suatu Negara; perlakuan sama terhadap investor asing dan tidak adanya pembedaan dari investor domestik; insentif untuk penanaman modal; transparency, yaitu kejelasan mengenai peraturan perundangan, prosedur administrasi yang berlaku, serta kebijakan investasi; dan kepastian hukum, termasuk enforcement putusan-putusan pengadilan (Hartana, 2017: 72).

Selain itu, ada beberapa hal yang perlu diperhatikan dalam menarik masuknya investor dan yang paling penting merupakan menciptakan iklim investasi yang kondusif. Menurut Erman Rajagukguk suatu negara dapat dikatakan memiliki iklim investasi yang kondusif bila memenuhi syarat-syarat; pertama, ada economic opportunity (investasi mampu memberikan keuntungan ekonomis bagi investor); kedua, political stability (investasi akan sangat dipengaruhi stabilitas politik); ketiga, legal certainty atau kepastian hukum (Hartana, 2017: 73).

Iklim investasi di Indonesia yang masih belum kondusif menimbulkan kekhawtirankekhawatiran bagi para investor. Apalagi investasi di bidang pertambangan yang memerlukan dana besar dengan risiko yang relatif tinggi. Investasi di sektor pertambangan tinggi akan ketidakpastian dalam pendanaan perusahaan (Ingrit, Hermanto, Ferry, 2017: 92). Para investor merasa khawatir akan banyaknya risiko yang akan ditemui. Kondisi ini dipengaruhi oleh situasi hukum dan politik Indonesia yang tidak menentu. Dalam sebuah studi khusus untuk Indonesia, Goeltom (1997) menunjukkan stabilitas politik dinilai sebagai factor kebijakan yang paling penting, yang dipertimbangkan oleh investor asing (Jennifer McKay, Balbir Bhasin, 2001: 10). 
Investor yang menanamkan modal di negara-negara berkembang seperti Indonesia umumnya menuntut kesiapan negara tersebut dari aspek keamanan dan kepastian hukum dalam berinvestasi. Namun, hal ini belum sepenuhnya terwujud dalam industri pertambangan di dalam negeri. Manajemen buruk pemerintah dalam mengelola sektor pertambangan secara tidak langsung telah mengakibatkan kerugian negara secara materil. Artinya, potensi industri pertambangan dimana merupakan salah satu penyumbang bagi perkembangan perekonomian di Indonesia, tidak lagi secara maksimal memberikan kontribusi terhadap pendapatan negara dan memajukan perekonomian di daerah (Hartana, 2017: 75).

Disisi lain, kelemahan kapasitas perizinan dapat digunakan investor untuk mengambil keuntungan melalui gugatan hukum. IUP yang sengaja bermasalah terus dieksiskan yang pada akhirnya atas permasalahan itu diajukan gugatan untuk mendapatkan ganti rugi atas kesalahan prosedural pemberian izin dari pejabat atau petugas administrasi pemerintahan. Apalagi atas perusahaan pemilik izin itu terdapat investor asing yang sengaja menggunakan kesalahan pejabat atau petugas administrasi pemerintahan untuk diajukan gugatan ke forum arbitrase internasional (Ahmad Redi, 2017: 110).

4. Upaya-Upaya Sinkronisasi dan Alternatif Solusi Pengaturan Izin Usaha Pertambangan

Izin yang diterbitkan Departemen Energi dan Sumber Daya Mineral, Pemerintah Provinsi atau Kabupaten/Kota belum memberikan jaminan kepastian berusaha. Hal ini disebabkan setiap sektor yang berhubungan dengan masalah pertambangan mempunyai aturan sendiri dan tidak ada sinergi antara instansi pemerintah. Sehingga diperlukan koordinasi antar sektor dan Pemerintah Daerah yang menangani masalah pertambangan untuk mengurangi tumpang tindih kegiatan pertambangan. Koordinasi dapat dilaksanakan melalui produk hukum berupa Surat Keputusan Bersama antara Departemen ESDM dan Departemen Dalam Negeri untuk mengatur masalah koordinasi atau bahkan perlu diatur dalam Keputusan Presiden. Dalam koordinasi ini hal-hal yang perlu diperhatikan merupakan tugas dan fungsi masing-masing instansi, pemecahan masalah yang spesifik yang memerlukan penanganan secara khusus, saling memberikan informasi pada perkembangan kebijakan masing-masing sektor, serta percepatan perizinan dan evaluasi kegiatan.

Apabila koordinasi telah dilaksanakan dan menghasilkan Surat Keputusan Bersama maka diperlukan pemberian informasi dan sosialisasi kepada masyarakat termasuk investor. Sosialisasi hendaknya dapat dilakukan secara bersinergi dan saling mendukung. Dengan demikian sinergitas kegiatan tersebut dapat mendukung pembangunan dan menunjang peningkatan kesejahteraan rakyat. Pengelolaan pertambangan harus melibatkan seluruh stake holders yaitu Pemerintah, masyarakat (society) dan sektor swasta atau dunia usaha. Ketiga komponen tersebut saling berinteraksi dan menjalankan fungsinya masing-masing secara gotong royong. Pemerintah menciptakan lingkungan politik dan hukum serta kebijakan yang kondusif dan transparan, sektor swasta menciptakan pekerjaan dan pendapatan, sedangkan masyarakat (society) berperan positif dalam interaksi sosial, ekonomi dan politik khususnya dalam mendukung program pengelolaan pertambangan untuk pembangunan. 


\section{Simpulan}

Ketidaksinkronan pengaturan IUP yang terdapat dalam Undang-Undang Nomor 4 Tahun 2009 tentang Pertambangan Mineral dan Batubara dan Undang-Undang Nomor 9 Tahun 2015 tentang Perubahan Kedua Undang-Undang Nomor 23 Tahun 2014 tentang Pemerintahan Daerah berimplikasi kepada tidak tercapainya kepastian hukum dalam pengaturan izin usaha pertambangan sehingga berdampak pada berkurangnnya minat investor untuk melakukan kegiatan investasi pertambangan di Indonesia. Upaya yang dapat dilakukan yaitu dengan koordinasi antar sektor dan Pemerintah Daerah yang menangani masalah pertambangan melalui Surat Keputusan Bersama yang nantinya dapat disosialisasikan kepada masyarakat dan pelaku usaha.

\section{E. Saran}

Perlu segera dilakukan koordinasi antara Kementrian ESDM, Kementrian Dalam Negeri, dan Pemerintah Daerah melalui Surat Keputusan Bersama sehingga nantinya peraturan dalam pengelolaan pertambangan sesuai dengan tujuan dalam Pasal 33 ayat (3) Undang-Undang Dasar Negara Republik Indonesia Tahun 1945.

\section{F. Daftar Pustaka}

Ahmad Redi. 2017. Hukum Penyelesaian Sengketa Pertambangan Mineral dan Batubara. Jakarta: Sinar Grafika.

Ana Duek, Ridwan Rusli. 2010. “The Natural Resources Industry In Decentralised Indonesia: How Has Decentralisation Impacted The Minning, Oil and Gas Industries?”. CREA Discussion Paper 2010-25. University of Luxembourg.

Balbir Bhasin, Sivakumar Venkataramany. "Mining Law and Policy: Replacing the 'Contract of Work' Sisyem in Indonesia”. http://www.eisourcebook.org/cms/Mining\%20Law\%20 and\%20Policy\%20Evolution\%20in\%20Indonesia.pdf

Departemen Pendidikan Nasional, 2012. Kamus Besar Bahasa Indonesia. Jakarta: Pusat Bahasa.

Dian Cahyaningrum. 2014. "Pemberian Izin Usaha Pertambangan Oleh Bupati/Walikota (Studi di Kabupaten Kutai Timur, Provinsi Kalimantan Timur dan Kabupaten Konawi Provinsi Sulawesi Tenggara)”. Kajian Vol. 19 No.2 Juni 2014. DPR RI.

Dwi Aryani W. 2016. “Tumpang Tindih Perijinan Pertambangan dan Implikasi Terhadap Kepastian Hukum Berinvestasi”. Tesis. Fakultas Hukum Universitas Gadjah Mada.

Endang Sumiarni. 2013. Metodologi Penelitian Hukum dan Statistik. Yogyakarta: Universitas Atmajaya.

Hartana. 2017. "Hukum Pertambangan (Kepastian Hukum Terhadap Investasi Sektor Pertambangan Batubara di Daerah)". Jurnal Komunikasi Hukum Vol.3 No,1 Februari 2017. Fakultas Hukum dan Ilmu Sosial Universitas Pendidikan Ganesha Singaraja.

Ingrit, Hermanto Siregar, Ferry Syarifussin. 2017. "Factors Influencing Dividend Policy on Mining Companies Listed in Indonesia Stock Exchange 2011-2015”. International Journal 
of Administrative Science \& Organization. Vol. 24 Number 2, May 2017. Fakultas Ilmu Administrasi Universitas Indonesia.

Jazim Hamidi. 2015. "Management of Mining in Indonesia: Decentralization and Corruption Eradication". Jurnal of Law, Policy and Globalization. Vol. 44, 2015. Jember: International Knowledge Sharing Platform (IISTE).

Jennifer McKay, Balbir Bhasin. 2001. "Minning Law and Policy in Indonesia: Issues in current Practice that Need Reform”. Journal of Energy \& Natural Resources Law. Vol. 19 No.4 2001. International Bar Association.

J. Ronald Mawuntu. 2012. Konsep Penguasaan Negara Berdasarkan Pasal 33UUD 1945 dan Putusan Mahkamah Konstitusi. Jurnal Hukum UNSRAT Edisi KhususVol. XX/No.3/AprilJuni. Universitas Sam Ratulangi.

Komisi Pemberantas Korupsi (KPK). 2017. Penataan Izin Batubara dalam Koordinasi dan Supervisi KPK. Jakarta: Publish What You Pay Indonesia.

La Ode Mustafa Rufini, Syamsul Alam, dan Jamal Bake. 2016. "Policy Learning of Mineral Mining Management”. The International Journal of Engineering and Science (IJES). Vol.5 Issue.10. Halu Oleo University.

Nazaruddin Lathif. 2017. "Tinjauan yuridis Tentang Kewenangan Pemerintah Provinsi Dalam Penerbitan Izin Usaha Pertambangan Batubara”. Jurnal Panorama Hukum Vol.2 No.2 Desember 2017. Universitas Malang.

Soerjono Soekanto dan Sri Mamudji. 2007. Penelitian Hukum Normatif Suatu Tinjauan Singkat. Jakarta: PT. Raja Grafindo Persada.

Widhya Mahendra Putra. 2010. "Sinkronisasi Peraturan Perundang-Undangan Mengenai Izin Usaha Pertambangan Dalam Rangka Mewujudkan Pembangunan Nasional yang Berkelanjutan”. Skripsi. Surakarta: Universitas Sebelas Maret.

Zainudin Ali. 2009. Metode Penelitian Hukum. Jakarta: Sinar Grafika. 